\title{
In-vitro activity of fleroxacin against isolates causing complicated urinary tract infections and concentrations in seminal and prostatic fluid and in prostatic adenoma tissue
}

\author{
K. G. Naber ${ }^{a}$, F. Sörgel ${ }^{b}$, F. Kees ${ }^{c}$, H. Schumacher ${ }^{a}$, R. Metz ${ }^{b}$ and H. Grobecker ${ }^{c}$ \\ ${ }^{a}$ Urologic Clinic, Elisabeth Krankenhaus, Straubing; ${ }^{b} I B M P$-Institute for Biomedical \\ and Pharmaceutical Research, Nürnberg; ${ }^{c}$ Department of Pharmacology, University of \\ Regensburg, Regensburg, Federal Republic of Germany
}

\begin{abstract}
Fleroxacin is a new fluoroquinolone with a broad antibacterial spectrum and a serum half-life of about 8-12 h. Eighty percent of 400 isolates from complicated or hospital-acquired urinary tract infections were inhibited by a concentration of $1 \mathrm{mg} / 1$ and $95 \%$ by $4 \mathrm{mg} / 1$. As with other quinolones, fleroxacin is less active in acid urine (pH 5.4) than in Mueller-Hinton broth (pH 7.4).

In 12 healthy volunteers the concentrations of fleroxacin were measured in plasma and seminal and prostatic fluid 2, 4 and $12 \mathrm{~h}$ after an oral dose of $400 \mathrm{mg}$. The mean plasma concentrations of three or four volunteers at each time were $4 \cdot 2,3 \cdot 6$ and $1.2 \mathrm{mg} / \mathrm{l}$, respectively. The corresponding prostatic fluid/plasma ratios were $0.30,0.27$ and 1.96 , respectively. By concomittant administration of ioxitalamic acid it could be demonstrated that in samples obtained $12 \mathrm{~h}$ after administration urinary contamination must be considered. Fleroxacin is concentrated in seminal fluid by a median ratio of 1.7 .

In 13 elderly patients the prostatic fluid and prostatic adenoma tissue concentrations were determined one to four hours following oral administration of $400 \mathrm{mg}$. The concentrations in prostatic fluid were similar to those of volunteers. The tissue concentrations exceeded plasma concentrations by only about $10 \%$ (median).

Fleroxacin is very active against isolates causing complicated UTI. Concentrations in seminal and prostatic fluid and prostatic adenoma tissue are sufficiently high to treat bacterial prostatitis or vesiculitis caused by susceptible bacterial strains.
\end{abstract}

\section{Introduction}

Fleroxacin (Ro 23-6240) is a new fluoroquinolone with a broad antibacterial spectrum and a serum half-life of about 8-12 h (Weidekamm, Stöckel \& Dell, 1987).

Since resistant strains are frequently found in complicated or hospital-acquired urinary tract infections (UTI) (Naber et al., 1987), the in-vitro activity of fleroxacin was determined against isolates causing complicated UTIs in urological patients. In addition, in healthy volunteers the concentrations of fleroxacin were determined in seminal and prostatic fluid and in elderly patients undergoing transurethral resection of the prostate (TUR-P) in prostatic fluid and prostatic adenoma tissue. 


\section{Material and methods}

\section{In-vitro study}

Isolates cultured from the urine of 400 inpatients with complicated or hospitalacquired UTIs ( $\geqslant 10^{5} \mathrm{cfu} / \mathrm{ml}$ in two specimens within $48 \mathrm{~h}$ ) were stored on nutrient agar. Only first isolates from patients with infections caused by single strains during hospitalization were used in the study. The MIC's of fleroxacin were determined by the agar dilution technique with serial twofold dilutions of the antibiotics in MuellerHinton agar (Merck, Darmstadt, West Germany). Cultures were inoculated with $10^{4}$ cfu by a multipoint inoculator (Dynatech, Denkendorf, West Germany). After $18 \mathrm{~h}$ incubation at $37^{\circ} \mathrm{C}$ the MIC was determined as the lowest concentration of antibiotic inhibiting visible growth $(<10 \mathrm{cfu})$.

The bacteria studied were about one-third each of Escherichia coli, other Gramnegative strains, and Gram-positive strains (mainly Streptococcus faecalis and Staphylococcus epidermidis). For seven selected strains of different species MICs of fleroxacin, norfloxacin and ofloxacin were also determined by a broth dilution method in Mueller-Hinton broth ( $\mathrm{pH} \mathrm{7.4)}$ and urine ( $\mathrm{pH} \mathrm{5.4)} \mathrm{in} \mathrm{microtitre} \mathrm{plates} \mathrm{(Hoffmann-}$ La Roche, Basel, Switzerland).

\section{Study in volunteers}

In twelve healthy volunteers with a mean age $27 \cdot 1 \pm 2 \cdot 7$ years (mean \pm S.D.), a mean body weight of $76.7 \pm 4.4 \mathrm{~kg}$ (mean \pm S.D.) and a mean height $f 180.5 \pm 5.1 \mathrm{~cm}$ (mean \pm S.D.) concentrations of fleroxacin were measured in plasma, prostatic and seminal fluid. All volunteers except one, were non-smokers. The subjects fasted for $12 \mathrm{~h}$ before and $4 \mathrm{~h}$ after administration. In each volunteer sampling of prostatic fluid by massage of the prostate was followed by sampling of seminal fluid by masturbation at $2 \mathrm{~h}$ (group I, $n=4$ ), $4 \mathrm{~h}$ (group II, $n=4$ ), and $12 \mathrm{~h}$ (group III, $n=4$ ), respectively, after oral administration of $400 \mathrm{mg}$ fleroxacin. As a marker for urinary contamination of prostatic fluid $2.5 \mathrm{~g}$ of ioxitalamic acid $(5 \mathrm{ml}$ of Telebrix 300 Byk Gulden, Konstanz, West Germany) was given intravenously. In groups I and II ioxitalamic acid was given concomitantly with fleroxacin. Subjects were not allowed to void urine before samples were taken. In group III ioxitalamic acid was given 8 hours after fleroxacin. Subjects were instructed to void urine before prostatic fluid (12 h after administration of fleroxacin) was obtained.

Blood samples were taken by a scalp vein needle prior to drug administration and at intervals up to $12 \mathrm{~h}$. Samples were immediately centrifuged and stored at $-30^{\circ}$ (protected against light) until analysis. Concentrations in liquids were determined with a reversed phase HPLC-method.

\section{Study in patients}

Thirteen elderly patients aged 58-81 years (median 72 years) with body weight of $49-86 \mathrm{~kg}$ (median $73 \mathrm{~kg}$ ), height of $158-174 \mathrm{~cm}$ (median $170 \mathrm{~cm}$ ), serum creatinine of $0.8-1.4 \mathrm{mg} / \mathrm{dl}$ (median $1.0 \mathrm{mg} / \mathrm{dl}$ ) and haemoglobin of $12.2-17.9 \mathrm{~g} / \mathrm{dl}$ (median $14.7 \mathrm{~g} / \mathrm{d} 1)$ undergoing TUR-P were treated orally with fleroxacin $400 \mathrm{mg} 1-4 \mathrm{~h}$ preoperatively for antibiotic prophylaxis. Simultaneously ioxitalamic acid ( $2.5 \mathrm{~g})$ was 


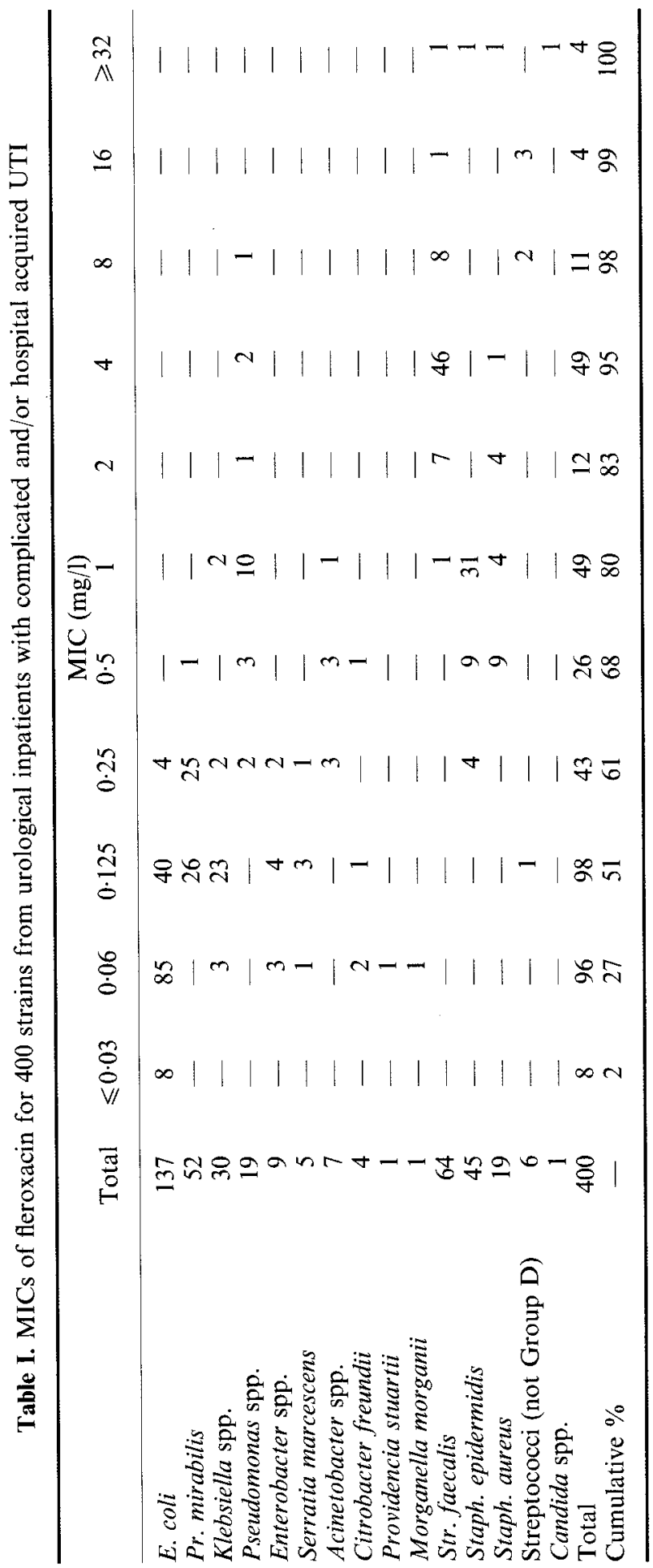


administered iv to monitor renal function (Naber et al., 1984). and as a marker of urinary contamination.

Immediately prior to TUR-P, prostatic fluid was obtained by prostatic massage. During the operation tissue samples of the two lateral and the median lobes of the prostate were collected for determination of tissue concentrations. Venous blood samples were taken prior to administration of fleroxacin and at the time of sampling the tissues. All samples were stored at $-70^{\circ} \mathrm{C}$ until analysis (HPLC). Tissue samples were homogenized (Sharpe \& Jackson, 1972) prior to analyis.

\section{Results}

\section{In-vitro study}

Eighty percent of the 400 strains were inhibited by $1 \mathrm{mg} / \mathrm{l}$ of fleroxacin and $95 \%$ by $4 \mathrm{mg} / \mathrm{l}$ (Table I). In general, fleroxacin was more active against Gram-negative than Gram-positive strains (Table I). Only one strain of Pseudomonas aeruginosa, one strain each of coagulase negative and positive staphylococci, ten strains of Str. faecalis and five strains of streptococci (not group D) showed MICs greater than $4 \mathrm{mg} / \mathrm{l}$. In urine (pH 5.4) all three quinolones were less active than in Mueller-Hinton broth (Table II) depending on the bacterial species. It was most marked with Proteus mirabilis because owing to its urease activity the urine becomes alkaline during incubation.

\section{Study in volunteers}

The concentrations of fleroxacin in plasma, in prostatic fluid and seminal fluid are shown in Figures 1 and 2. Fleroxacin was quickly absorbed in all 12 volunteers and showed a maximum plasma concentration of $5.42 \pm 1.41 \mathrm{mg} / 1$ after $1.3 \pm 0.78 \mathrm{~h}$. The

Table II. MIC of fleroxacin, norfloxacin and ofloxacin for seven strains of different species in Mueller-Hinton broth ( $\mathrm{pH} \mathrm{7.4)} \mathrm{and} \mathrm{acid} \mathrm{urine} \mathrm{(} \mathrm{pH} \mathrm{5.4)}$

\begin{tabular}{|c|c|c|c|c|c|c|}
\hline \multirow[b]{2}{*}{ Clinical Isolate } & \multirow[b]{2}{*}{ Medium } & \multicolumn{2}{|c|}{$\begin{array}{c}\text { Incubation } \\
\left(20 \mathrm{~h}, 37^{\circ} \mathrm{C}\right)\end{array}$} & \multicolumn{3}{|c|}{$\begin{array}{l}\text { Minimal inhibitory } \\
\text { concentration (MIC) }\end{array}$} \\
\hline & & $\begin{array}{c}\text { prior } \\
\mathrm{pH}\end{array}$ & $\begin{array}{c}\text { after } \\
\mathrm{pH}\end{array}$ & $\begin{array}{l}\text { fleroxacin } \\
\quad(\mathrm{mg} / 1)\end{array}$ & $\begin{array}{l}\text { norfloxacin } \\
\quad(\mathrm{mg} / \mathrm{l})\end{array}$ & $\begin{array}{l}\text { ofloxacin } \\
\text { (mg/l) }\end{array}$ \\
\hline \multirow[t]{2}{*}{ E. coli } & M-H & $7 \cdot 4$ & $7 \cdot 7$ & $\leqslant 0 \cdot 031$ & $\leqslant 0 \cdot 031$ & $\leqslant 0.031$ \\
\hline & Urine & $5 \cdot 4$ & 5.8 & 0.063 & $0 \cdot 125$ & $0 \cdot 125$ \\
\hline \multirow{2}{*}{ Pr. mirabilis } & M-H & $7 \cdot 4$ & 8.0 & $0 \cdot 063$ & $\leqslant 0.031$ & 0.063 \\
\hline & Urine & $5 \cdot 4$ & 8.0 & 8 & 8 & 32 \\
\hline \multirow{2}{*}{ K. pneumoniae } & M-H & $7 \cdot 4$ & $7 \cdot 2$ & 0.063 & 0.063 & 0.063 \\
\hline & Urine & $5 \cdot 4$ & $6 \cdot 7$ & 1 & 2 & 2 \\
\hline \multirow{2}{*}{ Ps. aeruginosa } & M-H & $7 \cdot 4$ & 8.0 & 1 & 0.25 & 0.5 \\
\hline & Urine & $5 \cdot 4$ & 6.7 & 4 & 4 & 4 \\
\hline \multirow[t]{2}{*}{ Ent. sakazakii } & M-H & $7 \cdot 4$ & $8 \cdot 0$ & 0.063 & $\leqslant 0.031$ & 0.031 \\
\hline & Urine & $5 \cdot 4$ & $6 \cdot 2$ & 0.25 & 0.5 & 0.5 \\
\hline \multirow[t]{2}{*}{ Str. faecalis } & M-H & $7 \cdot 4$ & $7 \cdot 5$ & 1 & 2 & 2 \\
\hline & Urine & $5 \cdot 4$ & 5.8 & $0 \cdot 125$ & 8 & 4 \\
\hline \multirow{2}{*}{ Staph. aureus } & $\mathrm{M}-\mathrm{H}$ & $7 \cdot 4$ & $7 \cdot 2$ & 0.5 & $0 \cdot 5$ & 0.25 \\
\hline & Urine & $5 \cdot 4$ & 7.0 & 0.5 & 1 & 0.5 \\
\hline
\end{tabular}

M-H, Mueller-Hinton broth. 


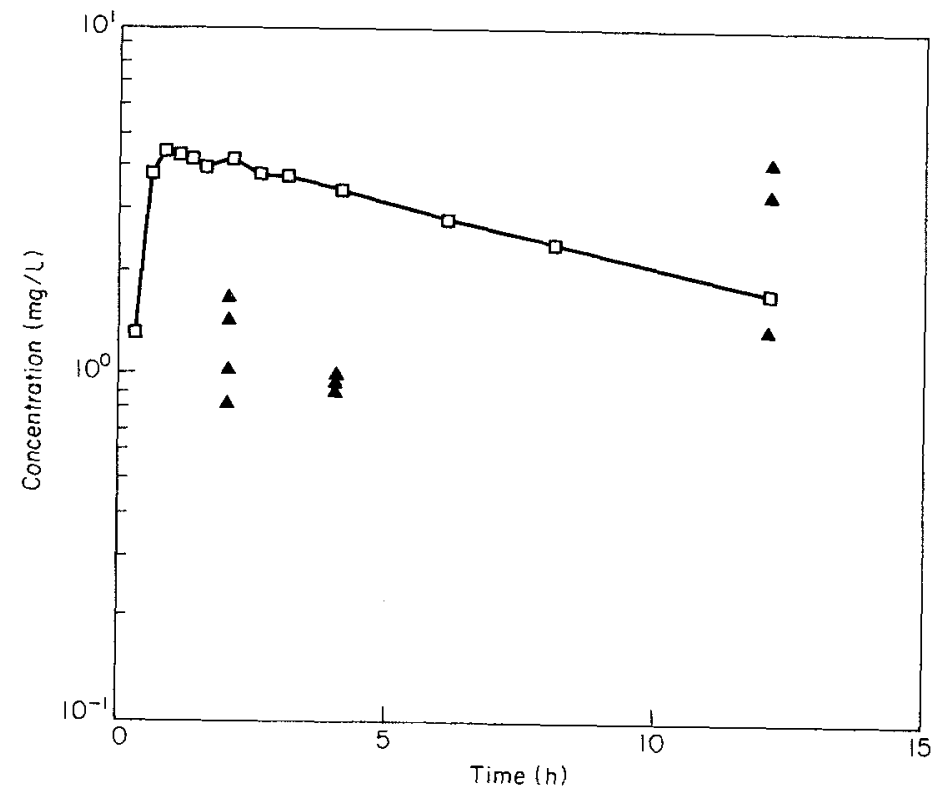

Figure 1. Mean plasma $(\square)$ and individual prostatic fluid $(\boldsymbol{A})$ concentrations of fleroxacin in 12 healthy volunteers after oral administration of $400 \mathrm{mg}$.

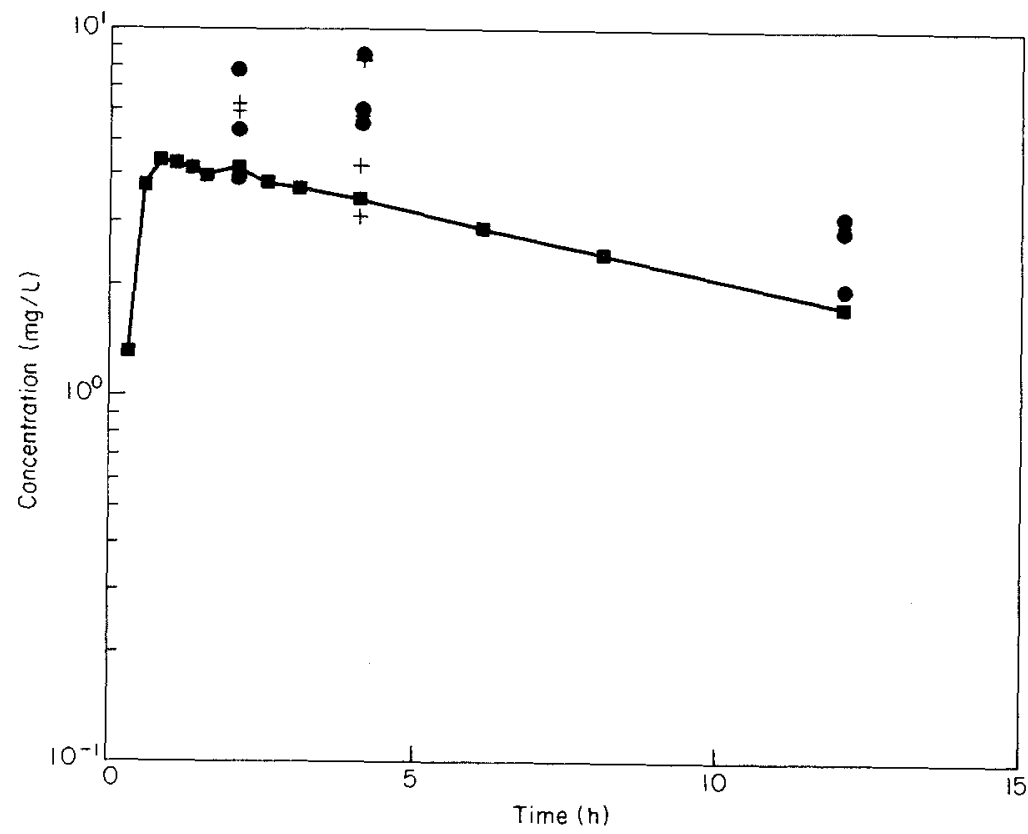

Figure 2. Mean plasma ( $\square$ ) and individual seminal fluid ( + , fraction 1; $\boldsymbol{\theta}$, fraction 2$)$ (split ejaculate) concentrations of fleroxacin in 12 healthy volunteers after oral administration of $400 \mathrm{mg}$. 


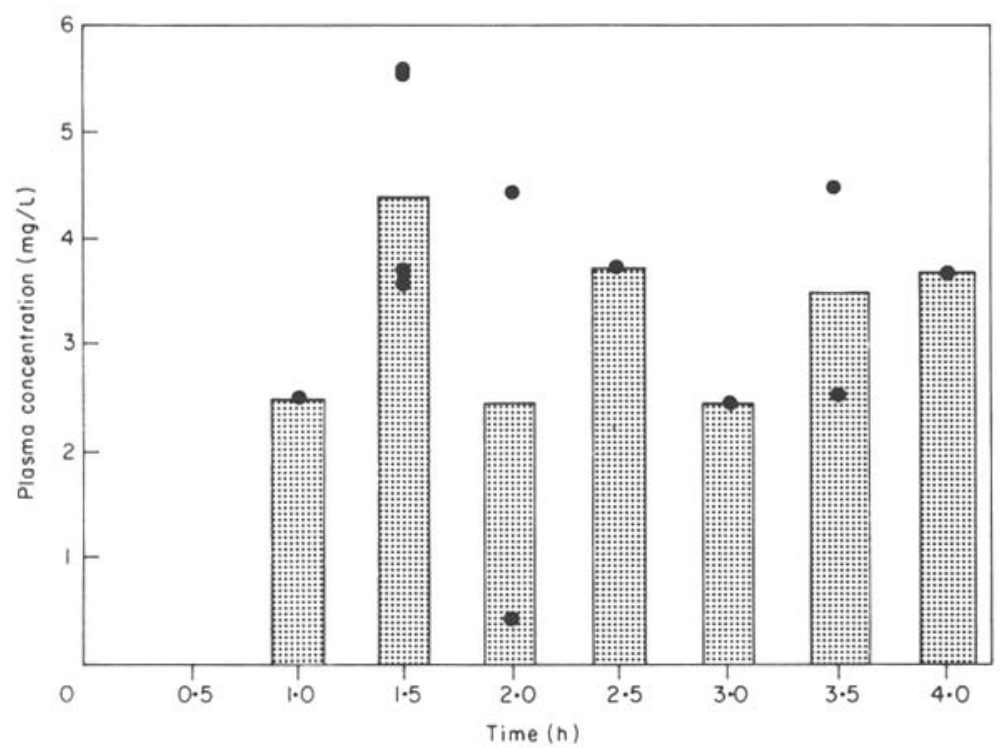

Figure 3. Plasma concentrations of fleroxacin in 13 elderly patients undergoing TUR of the prostate after oral administration of $400 \mathrm{mg}$.

concentrations decreased to $4 \cdot 17 \pm 0 \cdot 60 \mathrm{mg} / 1$ at $2 \mathrm{~h}$, to $3 \cdot 44 \pm 41 \mathrm{mg} / \mathrm{l}$ at $4 \mathrm{~h}$, and to $1.76 \pm 0.21 \mathrm{mg} / 1$ at $12 \mathrm{~h}$ after administration.

The prostatic fluid concentrations in groups I and II $(n=8)$ were between 0.84 and $1.69 \mathrm{mg} / 1$ (median $1.00 \mathrm{mg} / \mathrm{l}$, average $1.11 \mathrm{mg} / \mathrm{l}$ ) without a significant difference between the two groups. The fluid/plasma ratios ranged between 0.22 and 0.37 (median 0.28 , average $0 \cdot 29$ ). At $12 \mathrm{~h}$ (group III, $n=3$ ) the prostatic fluid concentrations were between 1.40 and $4.18 \mathrm{mg} / 1$ (median $3.39 \mathrm{mg} / 1,2.99 \mathrm{mg} / \mathrm{l}$ ) with fluid/plasma ratios between 0.89 and $2 \cdot 76$ (median $2 \cdot 24$, average $1 \cdot 96$ ).

The measurement of ioxitalamic acid in prostatic fluid of groups I and II showed concentrations below the limit of detection ( $2 \mathrm{mg} / \mathrm{l})$ except for one subject $(6 \cdot 2 \mathrm{mg} / \mathrm{l})$.

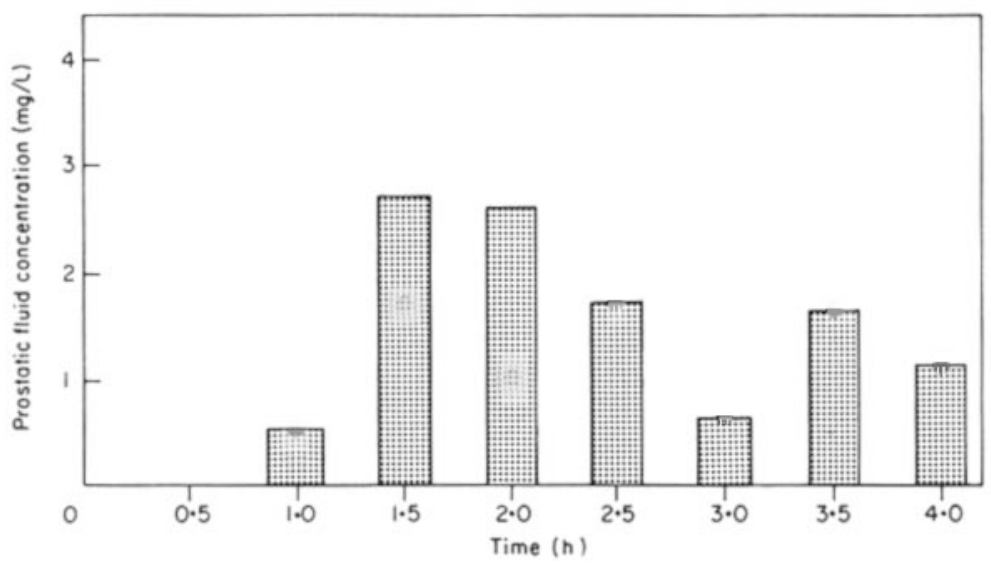

Figure 4. Prostatic fluid concentrations of fleroxacin in nine elderly patients undergoing TUR of prostate after oral administration of $400 \mathrm{mg}$. 


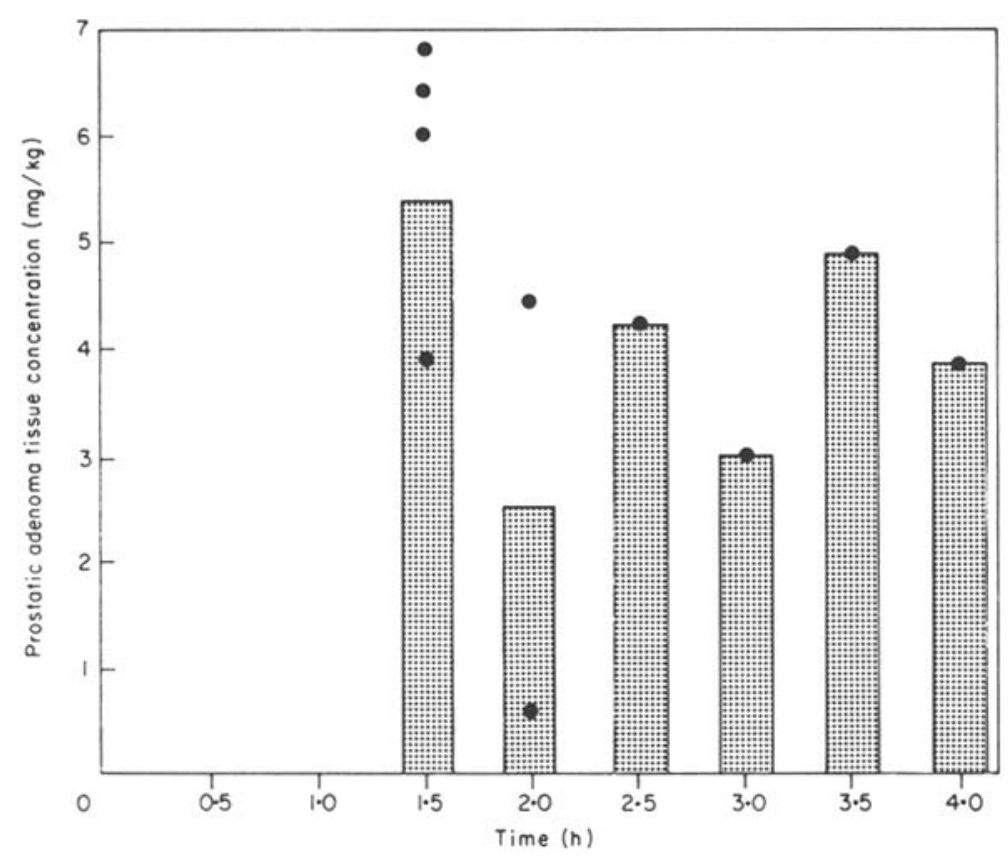

Figure 5. Prostatic adenoma tissue concentrations of fleroxacin in 10 elderly patients undergoing TUR of the prostate after oral administration of $400 \mathrm{mg}$.

In volunteers of group III, however, the concentrations were between 141 and $445 \mathrm{mg} / 1$ (median $233 \mathrm{mg} / \mathrm{l}$ ) confirming that ioxitalamic acid is a reliable marker for urinary contamination.

Seminal fluid was collected as split ejaculate in two portions. Concentrations between fraction 1 and fraction 2 did not differ significantly. The following values refer to fraction 2. The concentrations of fleroxacin in seminal fluid (Figure 2) in groups I and II were between 3.95 and $8.61 \mathrm{mg} / \mathrm{l}$ (median $5.80 \mathrm{mg} / \mathrm{l}$ ) without a statistical difference between the two groups. The corresponding fluid/plasma ratios ranged from 0.9 to 2.3 (median $1 \cdot 7$ ). The concentrations of fleroxacin in group III were clearly lower, namely between 1.96 and $3.11 \mathrm{mg} / 1$ (median $2.89 \mathrm{mg} / \mathrm{l}$ ). The fluid/plasma ratios, however, were similar to those in groups I and II, namely between 1.6 and 1.8 (median $1 \cdot 7$ ). The concentrations of ioxitalamic acid in seminal fluid did not indicate significant urinary contamination.

\section{Study in patients}

The plasma concentrations of fleroxacin are shown in Figure 3. In 12 patients the concentrations after 1 and $4 \mathrm{~h}$ ranged from 5.5 to $2.4 \mathrm{mg} / \mathrm{l}$ (median $3.7 \mathrm{mg} / \mathrm{l}$ ). In one patient a plasma concentration of $0.44 \mathrm{mg} / \mathrm{l}$ was found after $2 \mathrm{~h}$. In nine patients concentrations of prostatic fluid could be obtained (Figure 3). The concentrations ranged from 0.53 to $4.15 \mathrm{mg} / \mathrm{l}$ (median $1.67 \mathrm{mg} / \mathrm{l}$ ) with fluid/plasma ratios ranging from $0 \cdot 21-2 \cdot 44$ (median $0 \cdot 37$ ). If a prostatic secretion/plasma ratio for ioxitalamic acid of greater than 1.0 is accepted as an indication for urinary contamination, only five patients were probably not contaminated. In these five patients the prostatic fluid 
concentrations ranged from $0.53-4.15 \mathrm{mg} / \mathrm{l}$ (median $1.71 \mathrm{mg} / \mathrm{l}$ ) with fluid/plasma ratios ranging from $0 \cdot 21$ to 0.93 (median $0 \cdot 31$ ).

The concentrations in prostatic tissue $1 \cdot 5-4 \cdot 0 \mathrm{~h}$ after oral administration of $400 \mathrm{mg}$ of fleroxacin are shown in Figure 5. In 10 patients the tissue concentrations ranged from $2.98 \mathrm{mg} / \mathrm{kg}$ to $6.82 \mathrm{mg} / \mathrm{kg}$ (median $4.35 \mathrm{mg} / \mathrm{kg}$ ). In one patient a tissue concentration of $0.58 \mathrm{mg} / \mathrm{kg}$ with a corresponding plasma concentration of $0.44 \mathrm{mg} / 1$ was found. The tissue/plasma ratios in all 11 patients ranged from 1.00 to 1.92 (median $1 \cdot 10$ ). In ten patients the ratios were between 1.00 and 1.32 (median 1.09).

\section{Discussion}

Fleroxacin is highly active against Gram-negative and Gram-positive strains causing complicated and/or nosocomial UTI. As other quinolones (Shah, Ottrad \& Stille, 1983; Shah, Schützeichel \& Stille, 1984) its activity is diminished in acid urine depending on the bacterial species. The urinary concentrations, however, are several folds higher than the MIC in urine.

The concentrations in prostatic fluid following an oral dose of $400 \mathrm{mg}$ are sufficiently high to treat fully sensitive strains (MIC $\leqslant 1 \mathrm{mg} / \mathrm{l})$. Since volunteers had to void urine between 4 and $12 \mathrm{~h}$ after the oral dose of fleroxacin, urinary contamination of prostatic fluid collected at $12 \mathrm{~h}$ after administration could be demonstrated. Therefore, concentrations measured in prostatic fluid after voiding are not valid and this applies to all studies performed in the past. The prostatic fluid concentrations measured in elderly patients were in a similar range if the same precautions are taken. Since concentrations in prostatic fluid can only be measured before voiding, the time after administration is limited. Up to $4 \mathrm{~h}$ it could not be demonstrated that fleroxacin is concentrated in prostatic fluid.

The concentrations of fleroxacin in seminal fluid, in which urinary contamination does not play a major role, exceeded plasma concentrations by a median ratio of 1.7 . Therefore, it can be concluded that fleroxacin is concentrated in seminal fluid.

The concentrations of fleroxacin in prostatic adenoma tissue exceeded plasma concentrations by about $10 \%$.

From these in-vitro and in-vivo studies it can be concluded that fleroxacin is active against almost the total spectrum of bacteria causing complicated and/or hospital acquired UTIs. In bacterial prostatitis and vesiculitis concentrations of fleroxacin in seminal and prostatic fluid and in prostatic adenoma tissue are sufficiently high to treat infections with susceptible strains.

\section{References}

Naber, K., Kees, F., Adam, D., Meyer, G. P., Johnson, L. C., Letzel, H., et al. (1984) Vergleichende untersuchung zur pharmakokinetik von cefotetan und cefotaxim bei gesunden probanden. Zeitschrift für Antimikrobielle Antineoplastische Chemotherapie 2, $161-74$.

Naber, K. G., Bauernfeind, A., Dietlein, G. \& Wittenberger, R. (1987). Spektrum und sensibilität der erreger von harnwegs-infektionen bei stationären urologischen patienten in korrelation zu klinischen aspekten. Urologe B 27, 157-64.

Shah, P. M., Ottrad, M. \& Stille, W. (1983). In vitro activity of norfloxacin in urine compared to that of cinoxacin, nalidixic acid and pipemidic acid. European Journal of Clinical Microbiology 2, 271-4. 
Shah, P. M., Schützeichel, W. \& Stille, W. (1984). Einfluß von urin und plasmawasser auf die aktivität von gyrase-hemmern. Fortschritte des Antimikrobiellen Antineoplastische Chemotherapie 3-5, 549-55.

Sharpe, A. N. \& Jackson, A. K. (1972). Stomaching: a new concept in bacteriological sample preparation. Applied Microbiology 24, 175-8.

Weidekamm, E., Stöckel, K. \& Dell, D. (1987). A new trifluorinated quinolone: Ro 23-6240 (AM 833). Drugs under Experimental and Clinical Research 13, 85-90. 